\title{
PENGARUH KOMPOSISI RESIN POLIESTER TERHADAP KEKERASAN DAN KEKUATAN TARIK KOMPOSIT PAPAN PARTIKEL ONGGOK LIMBAH SINGKONG
}

\author{
Asroni $^{1 *}$, Deni Nurkholis ${ }^{2}$ \\ Universitas Muhammadiyah Metro ${ }^{1,2}$ \\ Jl. Ki Hajar Dewantara 15 A Metro, Lampung \\ asroni@engineer.com ${ }^{1}$, deninurkholis@yahoo.com²
}

\begin{abstract}
Abstrak
Perkembangan dan ilmu pengetahuan dalam segala bidang telah menuntut ketersediaan bahan teknik sebagai pendukung utamanya. Bahan-bahan teknik konvensional dari alam yang tidak dapat diperbarui akan terbatas ketersediaanya sehingga perlu dicari alternative bahanbahan teknik non konvensiaonal yang dapat diperbarui. Dalam membuat suatu perencanaan teknik memerlukan suatu bahan teknik yang kuat, tangguh, mudah dibentuk, ekonomis, tahan korosi serta ramah lingkungan. Sebagian besar material konvensional besifat homogeny dan isontropik, sedangkan material non konvensional yang bersifat homogeny dan anisotropic.Tujuan dari pnelitian ini adalah mengetahui nilai komposisi yang baik resin poliester yang diperkuat bahan onggok (limbah singkong) dan mengetahui berapa nilai kekuatan tarik dan kekerasan komposisi yang diperkuat bahan onggok (limbah singkong).Komposit adalah material yang trbentuk dari kombinasi dua atau lebih material sehingga di hasilkan matrial komposit yang mempunyai sifat makanik dan karakteristik yang berbeda dari matrial pmbentuknya.Serbuk onggok yang digunakan sudah mengalami perlakuan penjemuran dan pengayakan untuk mencari ukuran 20 mesh unsaturated resin polyester YUKALAC 157 BQTN-EX. . Komposit dibuat dengan cara manual dengan komposisi resin 40\%:60\%,50\%:50\%,60\%:40\%. Dari hasil pengujian tarik yang didapat maka dapat disimpulkan bahwa fraksi volume 40\%:60\%, 50\%:50\% dan 60\%:40\% yaitu sebesar 21,68 $\mathrm{N} / \mathrm{mm}^{2}, 14,35 \mathrm{~N} / \mathrm{mm}^{2}$, dan $18,75 \mathrm{~N} / \mathrm{mm}^{2}$. Hal ini menyatakan bahwa pada komposit $50 \%$ memiliki nilai kuat tarik terendah yaitu $14,35 \mathrm{~N} / \mathrm{mm}^{2}$ dikarenakan timbul void (gelembung udara) sehingga, kerapatan partikel dan matrik rendah, sehingga daya ikat partikel sebagai penguat juga rendah hal ini juga bisa disebabkan ikatan antar partikel yang kurang kuat menyebabkan mudah terjadinya gelembung udara (Void). Adapun hasil pengujian yang didapat nilai kekerasan dengan fraksi volume 40\%:60\%, 50\%:50\% dan 60\%:40\% yaitu sebesar 116,77 HRR, 100,31 HRR, dan 97,9 HRR. Dari hasil pengujian yang dilakukan di di B4T Bandung didapat bahwa, hasil kekuatan tarik rata-rata dengan fraksi volume resin 40\%:60\%,50\%:50\%, 60\%:40\% sebesar 21,68 $\mathrm{N} / \mathrm{mm}^{2}, 14,35 \mathrm{~N} / \mathrm{mm}^{2}$, dan 18,75 $\mathrm{N} / \mathrm{mm}^{2}$. Hasil kekerasan rata-rata dengan fraksi volume resin 40\%:60\%,50\%:50\%, 60\%:60\% sebesar 116,77 HRR, 100,31 HRR dan 97,9 HRR.
\end{abstract}

Kata kunci: Komposit, Serbuk Onggok Limbah Singkong, Resin polyester, Kekerasan, Kekuatan Tarik.

\section{Pendahuluan}

Limbah singkong terdiri dari beberapa macam antara lain Air, Kulit singkong, Onggok. Pemanfaatan limbah singkong khususnya untuk limbah padat atau onggok sekarang ini masih digunakan sebagai campuran pakan ternak, dan sebagai campuran bahan makanan. Partikel onggok sangat digunakan sebagai bahan penguat komposit karena bentuk dan karakteristiknya sama dengan serbuk kayu. 


\section{Tinjauan Teoritis}

\section{a) Komposit}

Komposit adalah suatu material yang terbentuk dari kombinasi dua atau lebih material sehingga dihasilkan material komposit yang mempunyai sifat mekanik dan karakteristik yang berbeda dari material pembentuknya. Komposit memiliki sifat mekanik yang lebih bagus dari logam, kekakuan jenis (modulus Young/density) dan kekuatan jenisnya lebih tinggi dari logam.

Penjelasan lain tentang komposit juga di utarakan oleh (Gapsari, 2013), Komposit adalah suatu material yang terbentuk dari kombinasi dua atau lebih material pembentuknya melalui pencampuran yang tak homogen, dimana sifat mekanik dari material pembentuknya berbeda-beda. Dikarenakan karakteristik pembentuknya berbeda-beda, maka akan dihasilkan material baru yaitu komposit yang mempunyai sifat mekanik dan karakteristik yang berbeda dari material-material pembentuknya. [1]

Komposit memiliki sifat mekanik yang lebih bagus dari logam, kekakuan jenis (modulus Young/density) dan kekuatan jenisnya lebih tinggi dari logam. Beberapa lamina komposit dapat ditumpuk dengan arah orientasi serat yang berbeda, gabungan lamina ini disebut sebagai laminat. Secara umum material komposit tersusun dari dua komponen utama yaitu matrik (bahan pengikat) dan filler (bahan pengisi). Filler adalah bahan pengisi yang digunakan dalam pembuatan komposit, biasanya berupa serat atau serbuk.

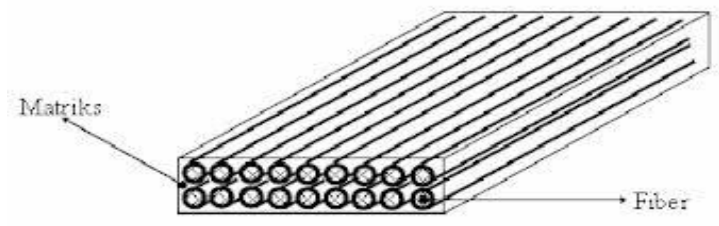

Gambar 1. Fibrous Composites [2]

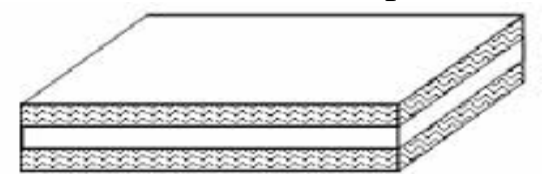

Gambar 2. Laminated Composites [2]

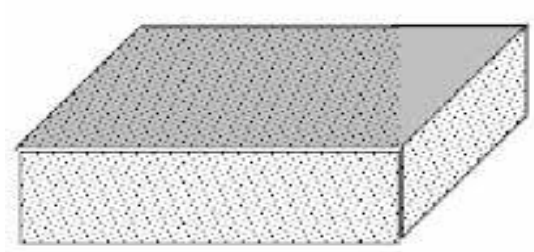

Gambar 3. Particulate Composite [2]

Tabel 1. Sifat Fisis dan Mekanis Papan Partikel dengan Berbagai Standar

\begin{tabular}{|c|c|c|c|}
\hline No. & $\begin{array}{l}\text { Sifat Fisis } \\
\text { Mekanis }\end{array}$ & $\begin{array}{c}\text { SNI } \\
03- \\
2105- \\
1996\end{array}$ & $\begin{array}{c}\text { JIS A } \\
5908 \text { - } \\
2003\end{array}$ \\
\hline 1 & $\begin{array}{l}\text { Kerapatan } \\
(\mathrm{gr} / \mathrm{cm} 3)\end{array}$ & $0,5-0,9$ & $0,4-0,9$ \\
\hline 2 & Kadar air (\%) & $<14$ & $5-13$ \\
\hline 3 & $\begin{array}{c}\text { Daya serap air } \\
(\%)\end{array}$ & - & - \\
\hline 4 & $\begin{array}{c}\text { Pengembangan } \\
\text { tebal }(\%)\end{array}$ & $\begin{array}{c}\text { Maks } \\
12\end{array}$ & $\begin{array}{c}\text { Maks } \\
12\end{array}$ \\
\hline 5 & $\operatorname{MOR}\left(\mathrm{kg} / \mathrm{cm}^{2}\right)$ & Min 80 & Min 80 \\
\hline 6 & $\operatorname{MOE}\left(\mathrm{kg} / \mathrm{cm}^{2}\right)$ & $\begin{array}{c}\text { Min } \\
15000\end{array}$ & $\begin{array}{c}\text { Min } \\
20000\end{array}$ \\
\hline 7 & $\begin{array}{l}\text { Internal Bond } \\
(\mathrm{kg} / \mathrm{cm} 2)\end{array}$ & $\begin{array}{c}\text { Min } \\
1,5\end{array}$ & $\begin{array}{c}\text { Min } \\
1,5\end{array}$ \\
\hline 8 & $\begin{array}{l}\text { Kuat pegang } \\
\text { sekrup (kg) }\end{array}$ & Min 30 & Min 30 \\
\hline 9 & $\begin{array}{c}\text { Linear } \\
\text { Expansion }(\%)\end{array}$ & - & - \\
\hline 10 & $\operatorname{Hardness}(\mathrm{N})$ & - & - \\
\hline 11 & $\begin{array}{c}\text { Emisi } \\
\text { Formaldehyde } \\
(\mathrm{ppm})\end{array}$ & - & $\begin{array}{c}\text { Min } \\
0,3\end{array}$ \\
\hline
\end{tabular}

\section{b) Singkong}

Tanaman singkong (manihot esculente) merupakan tanaman yang memiliki kandungan gizi yang cukup lengkap. Kandungan zat dalam tanaman singkong ialah karbohidrat, fosfor, kalsium, vitamin c, protin, zat besi, dan vitamin b1. Seiring kemajuan teknologi, pemanfaatan tanaman singkong berkembang sebagai bahan baku industri. Secara umum merupakan jenis taanaman yang mempunyai potensi untuk di kembangkan sebagai bahan baku industri.[3] 
Ampas singkong atau onggok adalah jenis partikel yang diperoleh dari tanaman pertanian singkong, Pada tanaman pertanian singkong yang sudah tua atau yang sudah berumur 8 bulan. Tanaman ini biasa menghasilkan 3 sampai 4 buah setiap pohonya dan berbobot $4 \mathrm{~kg}$.

Tabel 2. komposisi kimia onggok limbah singkong [4]

\begin{tabular}{|c|c|}
\hline Komponen & Jumlah (\%) \\
\hline Air & $11 \%$ \\
\hline Serat Kasar & $1,16 \%$ \\
\hline Lemak & $0,32 \%$ \\
\hline Protein & $1,21 \%$ \\
\hline Pati & $12,41 \%$ \\
\hline
\end{tabular}

\section{c) Pengujian tarik}

Pengujian tarik adalah macam pengujian yang paling sering dilakukan pada suatu benda, sehingga biasanya pada suatu bahan tersebut tercantum nilai kekuatan atau tenggangan tarik dan angka kekerasanya pengujian tarik dilakukan pada mesin uji tarik tersendiri ataupun universal adapun prinsip pengujianya adalah bahwa pada benda uji dengan ukuran tertentu diberikan beban tarik yang teratur dan merata.

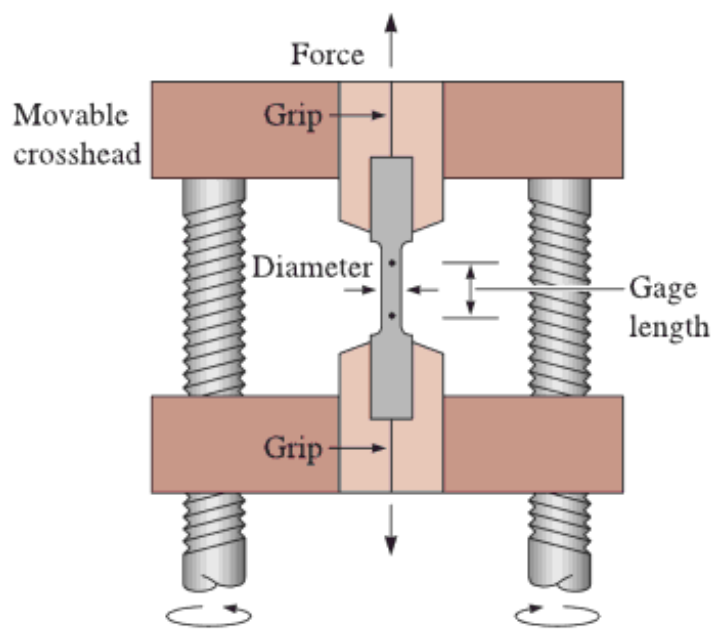

Gambar 4. Mesin Uji Tarik [5]

$$
\begin{gathered}
\text { Dimana }: P=\text { beban ulur } \\
A_{0}=\text { Luas penampang } \\
\text { awal }
\end{gathered}
$$

b. Tegangan tarik:

$$
\begin{aligned}
& \sigma_{t} \\
& =\frac{F}{A_{0}} \mathrm{~kg} / \mathrm{mm}^{2}
\end{aligned}
$$

Dimana $: F \quad=$ Beban maksimum penampang awal

c. Tegangan patah:

$$
\sigma_{\text {patah }}=\frac{F_{\text {max }}}{A_{0}} \mathrm{~kg} / \mathrm{mm}^{2}
$$

Dimana : $F_{\max }=$ Beban patah

awal

$$
A_{0} \quad=\text { Luas penampang }
$$

d. Regangan

$$
\begin{aligned}
& £=\frac{L u-L o}{L o} 100 \% \\
& \text { Dimana: } L u=\text { panjang setelah } \\
& \text { patah } \\
& \text { ( } \mathrm{mm}) \\
& \text { Lo = panjang awal }(\mathrm{mm})
\end{aligned}
$$

e. Kontraksi

$$
\begin{gathered}
E=\frac{S u-S o}{S o} 100 \% \\
\text { Dimana: So }=\text { luas penampang awal } \\
\quad(\mathrm{mm}) \\
\mathrm{Su}=\text { luas penampang setelah } \\
\text { patah }(\mathrm{mm})
\end{gathered}
$$

\section{f. Modulus elastis}

Dimana:

$$
\mathrm{E}=\frac{\tau_{\text {proporsional }}}{\epsilon_{\text {proporsional }}} \mathrm{kg} / \mathrm{mm}^{2}
$$

$$
\begin{gathered}
\text { tegangan proporsinal }=\frac{\text { beban proporsional }}{\text { luas penampang awal }} \mathrm{kg} / \mathrm{mm}^{2} \\
\text { tegangan proporsinal }=\frac{\text { panjang proporsional }}{\text { panjang awal }}
\end{gathered}
$$

1. Rumus perhitungan

a. Tegangan ulur:

$$
\sigma_{\text {ulur }}=\frac{p}{A_{0}} \mathrm{~kg} / \mathrm{mm}^{2}
$$




\section{Metode Penelitian}

\section{a) Prosedur Penelitian}

\section{Persiapan Sampel}

Bahan yang akan digunakan sebagai bahan pengisi berupa serbuk onggok yang disaring menggunakan mess dengan ukuran 20 mess.

Pembuatan Cetakan

Bahan yang digunakan untuk cetakan ini adalah plat besi, hal ini dikarenakan hasil cetakan lebih mudah dalam pelepasan. Spesimen uji dibuat satu persatu sebanyak 18 buah dengan perincian 9 buah untuk uji tarik dan 9 buah untuk uji kekerasan. Adapun standar pengujian yang dilakukan adalah ASTM dengan rincian sbagai berikut:

- Uji Tarik menggunakan standar ASTM D-3039

- Uji kekerasan menggunakan standar ASTM D 18-08

- Agar tidak terjadi kesalahan dalam pembuatan benda uji, maka ukuran cetakan dibuat sedikit lebih besar yaitu 1-5 mm.

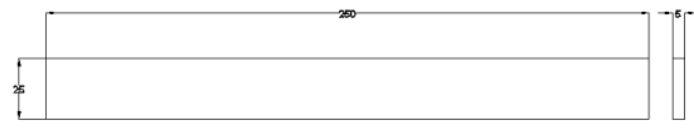

Gambar 5. Ukuran cetakan Uji Tarik ASTM D-3039 [6]
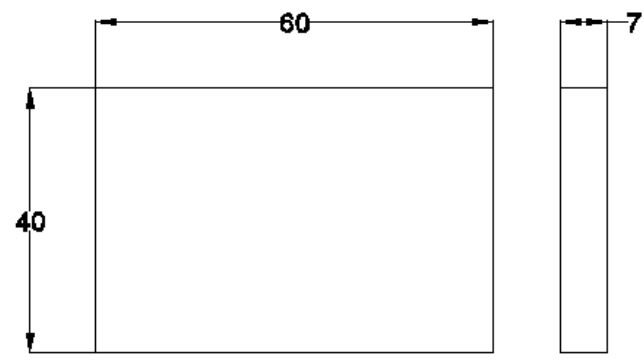

Gambar 6. Ukuran cetakan Uji Kekerasan ASTM D 785 [6]

Proses Pembuatan

Adapun tahap pembuatan komposit papan partikel ini adalah sebagai berikut:

a) Partikel dibuat dari serpihan limbah onggok, b) Pemisahan serbuk onggok akasia dengan ukuran 20 mess.

c) Cetakan dibersihkan, kemudian di lapisi alumunium foil dan oli secara merata agar komposit tidak menempel pada cetakan

d) Pencampuran partikel dengan perekat resin polyester dengan ukuran yang sudah ditentukan resin $40 \%: 60 \%$ ,50\%:50\%,60\%:40\% dilakukan hingga homogen,

e) Pembentukan papan partikel dilakukan di atas cetakan yang sudah ditentukan.

f) Setelah itu dilakukan pengeringan selama 5-10 jam dan apabila masih belum kering maka proses pengeringan dapat dilakukan lebih lama.

g) Sebelum dilakukan pengujian, dilakukan proses pengkondisian selama 2 minggu, agar papan partikel kering secara maksimal. Setelah itu papan partikel dipotong untuk membuat contoh uji untuk pengujian.

\section{b) Proses Pengujian}

Uji Tarik

Kekuatan atau tegangan tarik, perpanjangan, modulus elastis, dan tegangan mulur, dari bahan komposit. Penguji tarik dilakukan pada mesin uji tarik tersendiri atau di mesin universal.

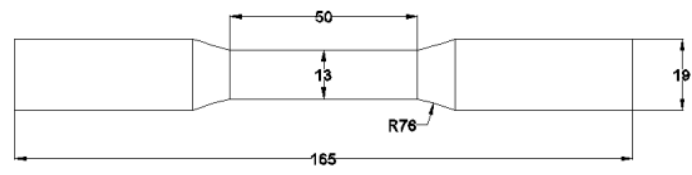

Gambar 7. Dimensi Uji Tarik D-3039 [6]

Uji kekerasan

Kekerasan merupakan kemampuan suatu matrial untuk bertahan dari proses abrasi (gesekan) atau tekanan kedalam (indentasi) oleh benda keras lain. Benda yang keras tersebut ditekan kedalam spesimen dengan menggunakan beban standar dan besar dari indentasi (baik itu area ataupun kedalaman) digunakan sebagai ukuran kekerasan matrial tersebut. 


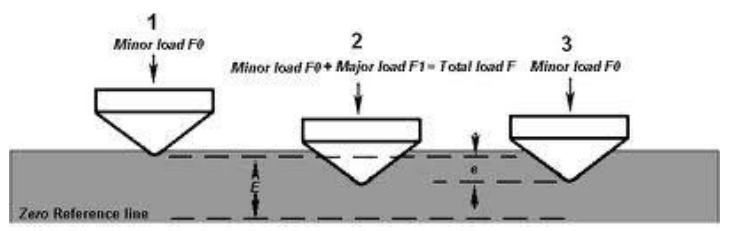

Gambar 3.6 Dimensi uji kekerasan

Langkah pengujian kekerasan dalam penelitian ini adalah sebagai berikut:

1. Siapkan benda uji dengaan ketentuan permukaannya harus rata

2. Letakkan benda uji pada landasan

3. Tempelkan indentor pada permukaan benda uji (hanya menempel tidak menekan)

4. Berikan pembebanan sesuai dengan jenis dan tabel bahan

5. Tunggu beberapa saat untuk waktu pembebanan

6. Angkat beban dari benda uji

7. Lakukan pengujian minimal $3 x$ pada tempat yang berbeda

8. Ukur diagonal bekas penekanan dan ambil rata-ratanya. Pengukuran dilakukan dengan kaca pembesar agar mendapatkan ukuran yang teliti

9. Hitung kekerasan bahan yang diuji.

\section{Hasil Dan Pembahasan}

\section{Hasil Uji Tarik}

Setelah melakukan pengujian tarik dengan standar ASTM D 3039 maka dapat dikumpulkan data-data pengujian tarik, adalah sebagai berikut:

Tabel 3 Nilai Kekuatan Tarik Komposit Partikel Serbuk Onggok atau limbah singkong.

\begin{tabular}{|c|c|c|c|}
\hline 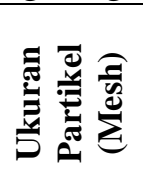 & 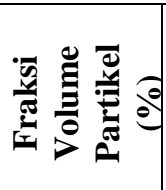 & 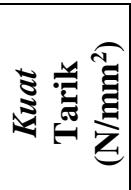 & 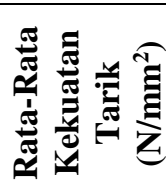 \\
\hline \multirow{3}{*}{20} & \multirow{3}{*}{40} & 20,040 & \multirow{3}{*}{21,68} \\
\hline & & 21,395 & \\
\hline & & 23,620 & \\
\hline \multirow{3}{*}{20} & \multirow{3}{*}{50} & 13,398 & \multirow{3}{*}{14,35} \\
\hline & & 14,487 & \\
\hline & & 10,565 & \\
\hline \multirow{3}{*}{20} & \multirow{3}{*}{60} & 18,415 & \multirow{3}{*}{18,75} \\
\hline & & 19,627 & \\
\hline & & 18,231 & \\
\hline
\end{tabular}

Pengujian tarik dilakukan menggunakan alat uji universal testing machine dan spesimen uji menggunakan standar ASTM D 3039. Adapun hasil yang didapat untuk nilai uji tarik komposit partikel $40 \%$ memiliki nilai rata-rata sebesar 21,68N/mm $\mathrm{mm}^{2}$, komposit partikel $50 \%$ memiliki nilai rata-rata sebesar 14,35 $\mathrm{N} / \mathrm{mm}^{2}$, komposit partikel $60 \%$ memiliki nilai rata-rata sebesar $18,75 \mathrm{~N} / \mathrm{mm}^{2}$.

Untuk mempermudah dalam membandingkan kekuatan tarik pada setiap fraksi volume serbuk, dibuat grafik hubungan antara rata-rata kekuatan tarik dengan fraksi volume serbuk.

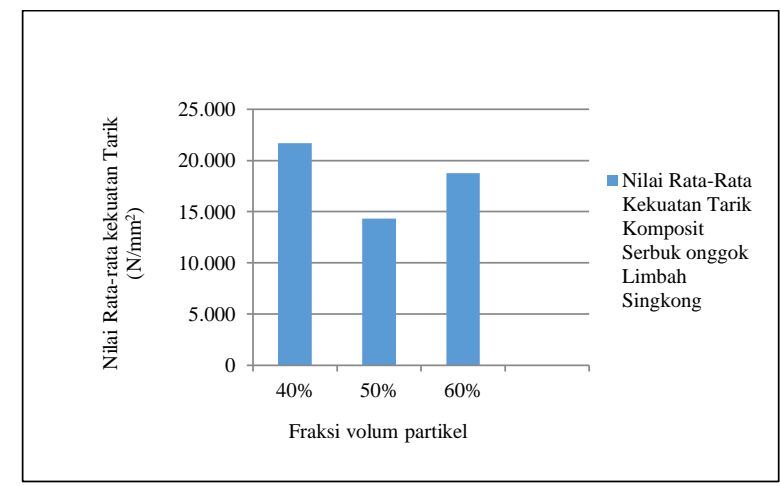

Gambar 8. Grafik Nilai Rata-Rata
Kekuatan Tarik

Dari grafik di atas maka dapat dilihat bahwa kekuatan tarik partikel onggok $50 \%$ sebesar $14,35 \mathrm{~N} / \mathrm{mm}^{2}$, untuk partikel onggok $60 \%$ kekuatan tarik mengalami peningkatan, yaitu sebesar $18,75 \mathrm{~N} / \mathrm{mm}^{2}$ peningkatan kekuatan tarik juga dialami komposit dengan partikel onggok $40 \%$ yaitu sebesar $21,65 \mathrm{~N} / \mathrm{mm}^{2}$.

Pada komposit $50 \%$ memiliki nilai terendah yaitu $14,35 \mathrm{~N} / \mathrm{mm}^{2}$, hal ini disebabkan void (gelembung udara) sehingga, kerapatan partikel dan matrik rendah, sehingga daya ikat partikel sebagai penguat juga rendah hal ini juga bisa disebabkan ikatan antar partikel yang kurang kuat menyebabkan mudah terjadinya gelembung udara pada komposit tersbut sehingga dapat menyebabkan tergesernya bahan penguat didalam matrik komposit diakibatkan adanya gaya dari luar permukaan komposit. 
Pada komposit $40 \%$ dan $60 \%$ mengalami peningkatan nilai kuat tarik sebesar $21,68 \mathrm{~N} / \mathrm{mm}^{2}$ dan $18,75 \mathrm{~N} / \mathrm{mm}^{2}$ karena kekuatan pada materialnya lebih merata atau lebih homogen, hal ini disebabkan adanya hubungan yang saling mendukung antara bahan penguat dan matrik dari komposit yang menyebabkan adanya ikatan yang kuat.

\section{Uji Kekerasan Rockwell}

Pengujian ini menggunakan metode pengujian kekerasan rockwell. Dengan metode uji ASTM D 785.

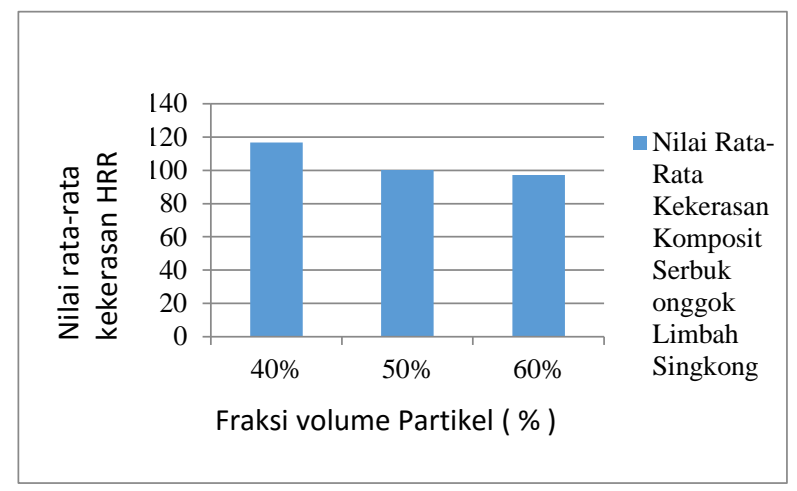

Tabel 4 Nilai Uji Kekrasan Komposit Partikel Serbuk Onggok atau limbah singkong

\begin{tabular}{|c|c|c|c|}
\hline $\begin{array}{c}\text { Ukura } \\
\text { n } \\
\text { partike } \\
\text { l } \\
(\text { Mesh })\end{array}$ & $\begin{array}{l}\text { Komposis } \\
\text { i Partikel }\end{array}$ & $\begin{array}{l}\text { Kekerasa } \\
\text { n (HRR) }\end{array}$ & $\begin{array}{c}\text { Rata- } \\
\text { rata } \\
(H R R \\
)\end{array}$ \\
\hline \multirow{4}{*}{20} & \multirow{4}{*}{$40 \%$} & 116 & \multirow{4}{*}{$\begin{array}{c}116,7 \\
7\end{array}$} \\
\hline & & 116,2 & \\
\hline & & 117,7 & \\
\hline & & 117,2 & \\
\hline \multirow{4}{*}{20} & \multirow{4}{*}{$50 \%$} & 103 & \multirow{4}{*}{$\begin{array}{c}100,3 \\
1\end{array}$} \\
\hline & & 98,5 & \\
\hline & & 102 & \\
\hline & & 97,75 & \\
\hline \multirow{4}{*}{20} & \multirow{4}{*}{$60 \%$} & 87 & \multirow{4}{*}{91,9} \\
\hline & & 93,25 & \\
\hline & & 96,75 & \\
\hline & & 90,75 & \\
\hline
\end{tabular}

Bila memperhatikan pada table 4 nilai kekerasan komposit serbuk onggok limbah singkong hasil pengujian untuk masingmasing fraksi volume serbuk cukup merata, hanya di komposit partikel $60 \%$ terjadi penurunan kekerasan. Hal ini disebabkan karena tidak ratanya partikel dan adanya void (gelembung udara) pada komposit. Tidak meratanya partikel mengakibatkan nilai kekerasan tidak merata. Void (gelembung udara) bisa timbul saat proses pengadukan resin dengan katalis. Saat pengadukan, udara luar masuk kedalam campuran sehingga timbul void dalam campuran. Hal ini yang menyebabkan turunnya nilai kekerasan.

Gambar 9 Grafik nilai rata-rata kekerasan serbuk onggok limbah singkong

Nilai kekerasan tertinggi dimiliki oleh fraksi volume partikel $40 \%$ yaitu sebesar 116,77 HR. Karena cukupnya volume matrik untuk mengikat serbuk onggok limbah singkong dalam komposit dan mampu menahan beban yang maksimal.

\section{Pembahasan}

Dari hasil pengujian tarik yang didapat maka dapat disimpulkan bahwa fraksi volume 40\%: 60\%, 50\%:50\% dan 60\%: $40 \%$ yaitu sebesar $21,68 \mathrm{~N} / \mathrm{mm}^{2}$, $14,35 \mathrm{~N} / \mathrm{mm}^{2}$, dan $8,75 \mathrm{~N} / \mathrm{mm}^{2}$. Hal ini menyatakan bahwa pada komposit $50 \%$ memiliki nilai kuat tarik terendah yaitu $14,35 \mathrm{~N} / \mathrm{mm}^{2}$ dikarenakan timbul void (gelembung udara) sehingga, kerapatan partikel dan matrik rendah, sehingga daya ikat partikel sebagai penguat juga rendah hal ini juga bisa disebabkan ikatan antar partikel yang kurang kuat menyebabkan mudah terjadinya gelembung udara (Void). Pada komposit 40\%:60\% dan 60\%: 40\% mengalami peningkatan kekuatan tarik sebesar 21,68 N/mm $\mathrm{mm}^{2}$ dan 18,75 N/mm². Dikarenakan keeseimbangan antara serbuk onggok dan matrik, sehingga daya ikat dalam komposit juga meningkat.

Adapun hasil pengujian yang didapat nilai kekerasan dengan fraksi volume $40 \%$ 
:60\%, 50\%:50\% dan 60\%: 40\% yaitu sebesar 116,77 HRR, 100,31 HRR, dan 97,9 HRR. Nilai kekerasrasan komposit serbuk onggok limbah singkong hasil pengujian untuk masing-masing fraksi volume serbuk cukup merata, hanya dikomposit serbuk 60\%: 40\% terjadi penurunan kekerasan, hal ini terjadi dikarenakan kekuatan dan materialnya kurang merata sehingga terjadinya adanya void (gelembung udara) pada komposit.

\section{Kesimpulan}

Dari hasil penelitian komposit serbuk onggok limbah singkong maka dapat diambil kesimpulan bahwa:

1. Komposisi 40\%:60\% merupakan nilai komposisi yang terbaik karena nilai kekerasan dan kekuatan tarik yang paling besar dibandingkan dengan yang lainya.

2. Kekuatan tarik dengan fraksi volume serbuk $40 \%, 50 \%$, dan $60 \%$ yaitu sebesar $21,68 \mathrm{~N} / \mathrm{mm}^{2}, 14,35 \mathrm{~N} / \mathrm{mm}^{2}$, dan $18,75 \mathrm{~N} / \mathrm{mm}^{2}$. Hal ini menyatakan bahwa peningkatan fraksi volume serbuk (sampai dengan 40\%) mampu meningkatkan kekuatan tarik komposit resin polyester.

3. Dari hasil pengujian didapat nilai kekerasan dengan fraksi volume $40 \%, 50 \%$, dan $60 \%$ yaitu sebesar 116,77 HRR, 100,31 HRR, dan 97,9 HRR. Secara umum peningkatan fraksi volume serbuk (sampai dengan 40\%) mampu meningkatkan kekerasan komposit resin polyester.

\section{Daftar Pustaka}

[1] Gapsari, F. (2013). Pengaruh Fraksi Volume Terhadap Kekuatan Tarik Dan Lentur Komposit Resin Berpenguat Serbuk Kayu. FEMA.

[2] Gay, D. (2003). Composite Materials Design and Aplications. Florida: CRC Press LLC.
[3] Suprapti, L. (2005). Teknologi Pengolahan Pangan TEPUNG TAPIOKA, Pembuatan \& Pemanfaatannya. Yogyakarta: Kanisius.

[4] Rahmarestia. (2007). Onggok

Terfermentasi dan

Pemanfaatannya. Yogyakarta:

FMIPA Uiversitas Negeri

Yogyakarta.

[5] Askeland, D. (2005). The Science \& Engineering of Materials. Boston: Cengage Learning.

[6] Schwartz, M. M. (1984). Composite Materials Handbook. New York: McGraw-Hill. 